\title{
PENGARUH CURRENT RATIO, DEBT TO EQUITY RATIO, FIRM SIZE TERHADAP NET PROFIT MARGIN PADA PERUSAHAAN PERDAGANGAN BESAR PRODUKSI YANG TERDAFTAR DI BURSA EFEK INDONESIA
}

\author{
Hantono \\ Universitas Pelita Harapan (UPH) - Kampus Medan \\ E-mail: hantono_78@yahoo.com
}

\begin{abstract}
This study aims to prove and analyze the effect of the current ratio, debt to equity ratio and firm size on the net profit margin of the large production trading companies listed on the Indonesia Stock Exchange in 2014-2018. The population in this study were 37 large production trading companies listed on the Indonesia Stock Exchange in 2014-2018. Of the 37 listed companies, 17 were selected as sample companies using purposive sampling. The results of the discussion show that simultaneously the results of tests conducted simultaneously Current Ratio, Debt to Equity Ratio and Firm Size affect the Net Profit Margin in large production large trading companies listed on the Indonesia Stock Exchange in 2014-2018. From the results of tests conducted partially the effect of the current ratio on the net profit margin, debt to equity ratio has a significant effect on the net profit margin, firm size does not affect the net profit margin on large production large trading companies listed on the Indonesia Stock Exchange in 2014 -2018 and While the coefficient of determination adjusted ( $R$ square) of 22.9\%. This means that $22.9 \%$ of the effect of net profit margin can be explained by variations of the three independent variables namely the current ratio, debt to equity ratio and firm size. While the remaining $77.1 \%$ is explained by other variables not examined in this study.
\end{abstract}

Keywords: current ratio, debt to equity ratio, firm size, net profit margin

\section{Pendahuluan}

Berita yang dikutip dari katadata.co.id pada tanggal 2 Desember 2019 terdapat tiga sektor yang memiliki kontribusi besar terhadap pertumbuhan ekonomi di Indonesia yaitu pada kuartal pertama 2019 dimana ketiga sektor itu adalah sektor industri memiliki kontribusi sebesar 20,07 persen, lalu perdagangan pada angka 12,20 persen, dan pertanian 12,65 persen. Namun, sektor industri mengalami peningkatan sebesar 3,86 persen, sementara terendah di bidang pertanian dan pertambangan. Hal ini menunjukkan angka yang lebih rendah dibanding dengan kuartal sebelumnya yang berada pada level 4,25 persen dan untuk sektor perdagangan mengalami peningkatan secara triwulanan. Kuartal pertama mengalami pertumbuhan sebesar 5,26 persen. Pada kuartal sebelumnya sektor perdagangan hanya mengalami pertumbuhan sebesar 4,39 persen.

Sementara itu pada perdagangan besar dan eceran jauh meningkat dibandingkan perdagangan mobil, sepeda motor, dan reparasinya. Namun, pertumbuhan perdagangan dengan negara-negara lain angkanya melambat seperti dibandingkan dengan negara Tiongkok menunjukkan 6,4 persen pada kuartal pertama 2019, dari sebelumnya 6,8 persen pada periode yang sama tahun sebelumnya. Sementara negara Singapura juga jauh lebih 
rendah, yaitu dari 4,7 persen menjadi 1,3 persen. Hal ini serupa juga terjadi pada negara Korea Selatan yang mengalami pertumbuhan perdagangannya sama dengan Indonesia yang menunjukkan angka sebesar 2,8 persen menjadi 1,8 persen. Sementara negara Amerika Serikat saja mengalami peningkatan angka dari 2,6 persen menjadi 3,2 persen.

Perusahaan perdagangan besar barang produksi adalah perusahaan yang memegang peranan yang sangat penting dalam kegiatan produksi nasional dan juga merupakan industri alat-alat berat yang berguna untuk proses produksi. Dalam buku-outlook-perekonomianindonesia-2019-mei menyatakan bahwa perdagangan global pada tahun 2018 melemah lebih cepat daripada yang diekspektasikan, bersamaan dengan penurunan aktivitas industri seperti yang dapat dilihat dalam grafik 1 yang menggambarkan ketidakpastian kebijakan perdagangan terus mengalami kenaikan serta memperkecil investasi dan perdagangan global.

Sementara Borrowing cost di negara-negara berkembang terus mengalami pengetatan serta yang diikuti depresiasi terhadap Dollar AS sehingga kondisi ini sangat mempengaruhi harga minyak yang bergejolak di paruh kedua tahun 2018 hal ini dikarenakan faktor suplai yang diikuti dengan penurunan tajam yang mendekati akhir tahun dan juga harga komoditas lain, terutama logam yang secara terus melemah dan merefleksikan tingginya tekanan perdagangan.

\section{Grafik 1. Pertumbuhan Volume \\ Perdagangan Global}

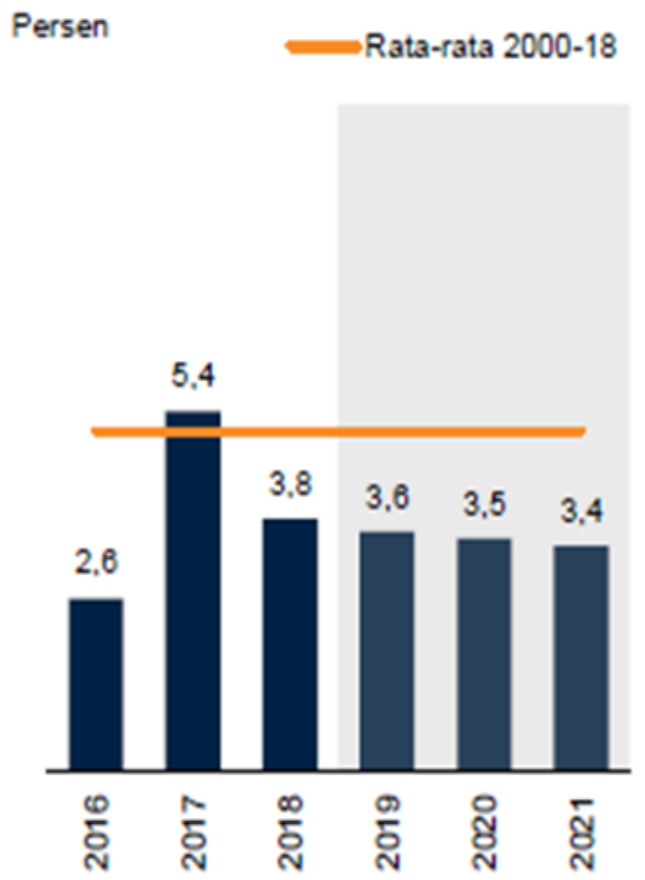

Sumber: Bank Dunia, 2019

Perumusan dari gambaran penelitian ini untuk melakukan analisis bagaimana current ratio, debt to equity ratio, dan firm size secara parsial dan secara simultan terhadap Net Profit Margin pada perusahaan perdagangan besar produksi yang terdaftar di Bursa Efek Indonesia tahun 2014-2018. 


\section{Tinjauan Literatur dan Pengembangan Hipotesis}

Net Profit Margin. Hery (2017 : 317) menyatakan bahwa margin laba bersih adalah rasio yang mengukur besarnya persentase laba bersih terhadap penjualan bersih.Hantono (2017:11), net profit margin menunjukkan tingkat keuntungan bersih (setelah dikurangi dengan biaya-biaya) yang diperoleh dari bisnis atau menunjukkan sejauh mana perusahaan mengelola bisnisnya. Fahmi (2015 : 81) memberikan gambaran bahwa margin laba bersih sama dengan laba bersih dibagi dengan penjualan bersih yang menunjukkan kestabilan kesatuan untuk menghasilkan perolehan pada tingkat penjualan khusus.

Current Ratio. Samryn (2013 : 411) current ratio memberikan gambaran bahwa rasio ini dinyatakan dengan desimal serta menunjukkan kemampuan perushaan membayar kewajiban jangka pendek dengan aktiva lancar serta berapa banyak aktiva lancar yang tersedia untuk menutupi tiap rupiah kewajiban jangka pendek. Munawir (2014 : 72) rasio ini memberikan perbandingan antara jumlah aktiva lancar dengan hutang lancar. Rasio ini menunjukkan bahwa nilai kekayaan lancar ( yang segera dapat dijadikan uang) ada sekian kalinya hutang jangka pendek. Bambang dan Mulyo (2012 : 106) menyatakan bahwa rasio lancar merupakan hasil pembagian antara aktiva lancar dengan hutang lancar yang artinya tingkat keamanan bagi kreditor jangka pendek.

Debt to Equity Ratio. Kasmir (2012:157) menyatakan bahwa rasio ini merupakan rasio yang digunakan yang dapat menilai utang dengan ekuitas. rasio ini dicari dengan cara membandingkan seluruh utang, termasuk utang lancar dengan seluruh ekuitas. Rasio ini berguna untuk mengetahui jumlah dana yang disediakan peminjam (Kreditor) dengan pemilik perusahaan. Dengan kata lain, rasio ini berfungsi untuk mengetahui setiap rupiah modal sendiri yang dijadikan jaminan utang. Samryn (2013: 420) merupakan rasio yang dapat mengukur sampai seberapa besar dana pinjaman yang digunakan untuk membiayai aktiva perusahaan. Hantono (2017 : 12) mengemukakan bahwa debt to equity ratio merupakan rasio yang menunjukkan sejauh mana modal sendiri menjamin seluruh hutang atau dengan kata lain sebagai rasio perbandingan antara dana pihak luar dengan dana pemilik perusahaan.

Firm Size. Sartono (2012:249) mengemukakan bahwa perusahaan besar yang sudah wellestablished akan lebih mudah memperoleh modal di pasar modal daripada perusahaan kecil. Hal ini disebabkan dalam kemudahan akses tersebut berarti perusahaan besar memiliki fleksibilitas yang lebih besar pula. Sunyoto (2013 : 116) mengemukakan bahwa ukuran perusahaan dapat dilihat pada total aktiva perusahaan. Riyanto (2015:299) mengatakan bahwa suatu perusahaan yang besar dimana sahamnya tersebar sangat luas sehingga setiap perluasan modal saham hanya akan mempunyai pengaruh kecil terhadap kemungkinan hilangnya atau tergesernya pengawasan dari pihak dominan terhadap perusahaan yang bersangkutan. Sebaliknya perusahaan yang kecil di mana sahamnya hanya tersebar di lingkungan kecil, penambahan jumlah saham akan mempunyai pengaruh yang besar terhadap kemungkinan hilangnya control pihak dominan terhadap perusahaan yang bersangkutan. Rodoni dan Ali (2014 : 193) untuk melakukan proksi size biasanya digunakan total aset perusahaan. Karena aset biasanya sangat besar nilainya dan untuk menghindari bias skala maka besaran aset perlu dikompres.

Keterkaitan Current Ratio Terhadap Net Profit Margin. Ritonga (2018) mengemukakan bahwa dengan current ratio (rasio lancar) rendah yang dimiliki perusahaan dapat menunjukkan rasio likuiditas yang tinggi, sedangkan rasio lancar yang tinggi akan menunjukkan adanya kelebihan aktiva lancar, yang akan mempunyai pengaruh yang tidak baik terhadap profitabilitas perusahaan. Kadir (2012) yang menyatakan bahwa current ratio 
tidak berpengaruh terhadap Net Profit Margin. Menurut Fercanza.et.al (2016) yang menunjukkan bahwa current ratio berpengaruh signifikan terhadap net profit margin. Hasil yang diperoleh pada tahapan pengujiannya menunjukkan bahwa semakin optimal posisi likuiditas perusahaan akan semakin dapat mendorong meningkatnya kemampuan perusahaan untuk dapat menghasilkan laba yang diukur dengan net profit margin. Angriani dan Hasanah (2017) yang menyatakan bahwa semakin optimal posisi likuiditas perusahaan akan semakin mendorong meningkatnya kemampuan perusahaan dalam menghasilkan laba yang diukur dengan net profit margin. Dari uraian di atas maka dapat disimpulkan bahwa:

$\mathrm{H}_{1}$ : Current Ratio memiliki pengaruh positif dan signifikan terhadap Net Profit Margin.

Keterkaitan Debt to Equity Ratio Terhadap Net Profit Margin. Kadir dan Phang (2012) menyatakan bahwa variabel debt to equity ratio memiliki pengaruh signifikan terhadap Net Profit Margin. Warsani dan Pramirza (2015), yang menunjukkan bahwa debt to equity ratio berpengaruh dan signifikan terhadap net profit margin. Dari penelitian ini dapat diketahui bahwa kedua variabel tersebut memiliki arah pengaruh yang negatif yang berarti bahwa hubungan DER dengan NPM bertolak belakang atau berbanding terbalik. NPM akan mengalami peningkatan apabila DER mengalami penurunan, begitu juga sebaliknya apabila DER mengalami peningkatan maka NPM akan mengalami penurunan. Koto (2017) menyatakan bahwa debt to equity ratio tidak memiliki hubungan yang signifikan terhadap Net Profit Margin, ini artinya menurunnya debt to equity ratio tidak mempengaruhi penurunan atau peningkatan Net Profit Margin. Hal ini dikarenakan besarnya nilai rata-rata yang ditunjukkan memberikan arti bahwa peningkatan debt to equity ratio akan berdampak terhadap munculnya beban bunga yang harus ditanggung oleh perusahaan sehingga akan berpengaruh terhadap perusahaan untuk menghasilkan laba bersih yang maksimal sebab beban biaya yang ditanggung semakin tinggi. Dari uraian di atas maka dapat disimpulkan bahwa:

$\mathrm{H}_{2}$ : Debt to Equity Ratio mempunyai pengaruh yang signifikan terhadap Net Profit Margin.

Keterkaitan Ukuran Perusahaan Terhadap Net Profit Margin. Suratminingsih (2018) menunjukkan bahwa ukuran perusahaan (Size) tidak berpengaruh signifikan terhadap profitabilitas (NPM) dimana secara umum ukuran perusahaan mempunyai pengaruh segala aspek keuangan perusahaan termasuk pencapaian laba yang menjadi tujuannya, karena masyarakat yang menjadi end user atas produk yang dihasilkan perusahaan food and beverages terutama karakter pada masyarakat perkotaan yang memandang bahwa semakin besar ukuran perusahaan (Size), maka akan semakin tinggi pula kualitas atas produk yang dihasilkan dan layanan konsumen yang lebih komprehensif atas produk tersebut sehingga masyarakat cenderung lebih banyak memilih untuk menggunakan produk yang dihasilkan oleh perusahaan besar daripada produksi oleh perusahaan kecil, sehingga berdampak pada tingkat profitabilitas perusahaan. Hastuti (2010) mengemukakan bahwa perusahaan besar mempunyai pengendalian dan tingkat daya saing yang tinggi dibandingkan dengan perusahaan kecil, sehingga bisa digunakan dengan perlindungan terhadap risiko ekonomis. Dari uraian di atas maka dapat disimpulkan bahwa:

$\mathrm{H}_{3}$ : Ukuran perusahaan memiliki pengaruh positif dan signifikan terhadap Net Profit Margin.

\section{Metode Penelitian}

Jenis penelitian ini menggunakan pendekatan kuantitatif dan data yang dipakai pada penelitian ini adalah data sekunder berupa laporan keuangan (financial report) pada perusahaan perdagangan besar produksi besar produksi yang terdaftar di Bursa Efek Indonesia dari tahun 2014-2018 yang berjumlah 37 perusahaan. Sampel pada penelitian ini 
diperoleh dari perhitungan purposive sampling pada perusahaan perdagangan besar produksi besar produksi yang terdaftar di Bursa Efek Indonesia dari tahun 2014-2018 sejumlah 17 perusahaan.

Variabel Dependen. Variable dependen dalam penelitian adalah net profit margin. Menurut Fahmi (2015 : 81), margin laba bersih sama dengan laba bersih dibagi dengan penjualan bersih. Adapun rumus rasio net profit margin adalah :

$$
\text { Net Profit Margin }=\frac{\text { Earning After Tax }(E A T)}{\text { Sales }}
$$

\section{Variabel Independen}

Current Ratio (X1). Menurut Bambang dan Mulyo (2012 : 106), current ratio atau biasa disebut dengan rasio lancar adalah hasil pembagian antara aktiva lancar dengan hutang lancar yang artinya tingkat keamanan bagi kreditor jangka pendek.

$$
\text { Current Ratio }=\frac{\text { Aktiva Lancar }}{\text { Hutang Lancar }}
$$

Debt to Equity Ratio (X2). Menurut Kasmir (2012 : 158), rumus untuk mencari debt to equity ratio dapat digunakan berbandingan antara total utang dengan total ekuitas sebagai berikut:

$$
\text { Debt to Equity Ratio }=\frac{\text { Total Hutang }}{\text { Total Ekuitas }}
$$

Firm Size (X3). Menurut Rodoni dan Ali (2014 : 193), Proksi size biasanya adalah total aset perusahaan. Karena aset biasanya sangat besar nilainya dan untuk menghindari bias skala maka besaran aset perlu dikompres. Secara umum proksi size dipakai logaritma (log) atau logaritma natural asset.

$$
\mathrm{Ln}=\text { Total } \text { asset }
$$

\section{Model Persamaan Regresi}

Model dalam persamaaan ini menggunakan regresi linear berganda sebagai berikut:

$$
\mathrm{NPM}=\alpha+\beta_{1} \mathrm{CR}+\beta_{2} \mathrm{DER}+\beta_{3} \text { Size }+\mathrm{e}
$$

Keterangan :

NPM = Margin Laba

$\alpha \quad=$ Koefisien konstanta

$\beta_{1}-\beta_{3}=$ koefisien regresi

$\mathrm{CR}=$ Aset Lancar

DER = Struktur Modal

Size = Ukuran Perusahaan

\section{Hasil Penelitian dan Pembahasan}

Statistik Deskriptif. Statistik Deskriptif adalah metode yang berkaitan dengan pengumpulan dan penyajian suatu data sehingga memberikan informasi yang berguna. Berdasarkan laporan keuangan pada periode 2014-2018 , maka dapat dilihat nilai minimum, maksimum, mean, dan standar deviation dari masing-masing variabel penelitian pada tabel 1. sebagai berikut : 
Tabel 1. Statistik Deskriptif

Descriptive Statistics

\begin{tabular}{lr|r|r|r|r} 
& N & \multicolumn{1}{c|}{ Minimum } & Maximum & \multicolumn{1}{c}{ Mean } & \multicolumn{1}{c}{ Std. Deviation } \\
\hline Current_Ratio & 85 & .15 & 72.22 & 3.4157 & 9.53923 \\
\hline DER & 85 & -4.55 & 82.38 & 2.5952 & 9.14110 \\
\hline Firm_Size & 85 & 21.72 & 32.39 & 26.9505 & 2.54544 \\
\hline NPM & 85 & -14.91 & .34 & -.5874 & 2.41257 \\
\hline Valid N (listwise) & 85 & & & & \\
\hline
\end{tabular}

Sumber : Hasil Pengolahan, 2020

Berdasarkan hasil perhitungan pada tabel 1 terdapat 85 sampel. Mean pada current ratio menunjukkan angka penyimpangan data yang tinggi dikarenakan nilai standar deviationnya lebih tinggi daripada nilai mean. Hasil tersebut menunjukkan data variabel current ratio mengindikasikan hasil yang kurang baik, dikarenakan standar deviation yang mencerminkan penyimpangan dari data variabel cukup tinggi karena lebih besar daripada nilai rata-ratanya. Hal yang beda juga terjadi pada variabel yang lain seperti debt to equity ratio, firm size dan Net Profit Margin.

Uji Asumsi Klasik. Asumsi klasik yang digunakan dalam penelitian ini menggunakan uji normalitas, uji multikolinearitas, uji heteroskedastisitas dan uji autokorelasi.

Hasil pengujian data menunjukkan bahwa data dalam penelitian ini mengalami masalah pada pengujian asumsi klasik, dimana uji multikolinearitas, uji heteroskedastisitas dan uji autokorelasi tidak memenuhi syarat. Oleh karena itu, peneliti melakukan transformasi dalam bentuk Ln terhadap variabel independen (Current Ratio, Debt to Equity Ratio, Firm Size) dan dependen (Net Profit Margin). Hasil pengujian normalitas data menggunakan analisis grafik dapat dilihat dari gambar 1 di bawah ini:

Histogram

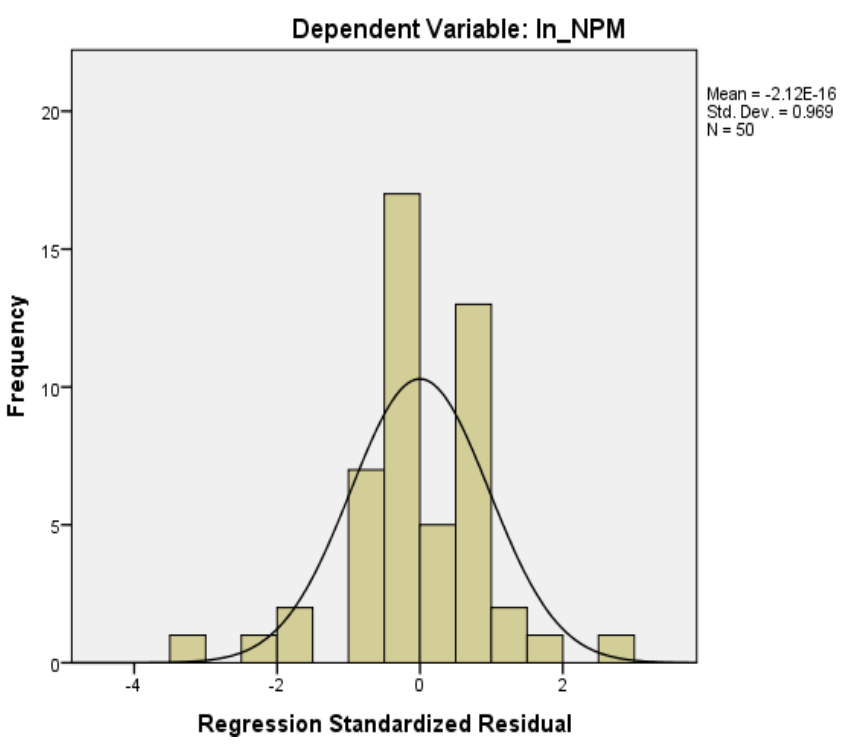

Gambar 1. Histogram Normalitas Data

Sumber : Hasil Pengolahan SPSS 24, 2020 
Pada Gambar 1 di atas menunjukkan garis kurva cenderung simetri (U) maka dapat dikatakan data berdistribusi normal. Hasil normal probability plot dalam penelitian ini dapat dilihat pada gambar 2 berikut :

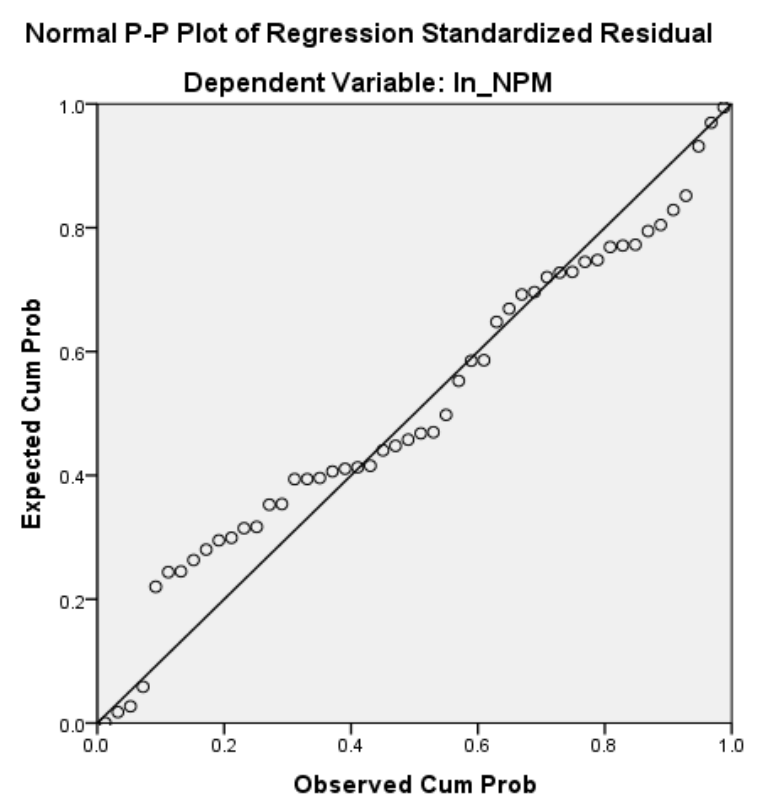

Gambar 2. Normal Probability Plots

Sumber : Hasil Pengolahan SPSS 24, 2020

Pada Gambar 2, grafik normal probability plots, titik-titik menyebar di sekitar garis normal dan mengikuti arah garis diagonal dan hal ini menunjukkan bahwa data terdistribusi secara normal, maka model regresi memenuhi asumsi normalitas. Hasil uji Kolmogorov Smirnov dapat dilihat pada tabel 2. sebagai berikut :

Tabel 2. Kolmogorov-Smirnov Test

One-Sample Kolmogorov-Smirnov Test

\begin{tabular}{llr} 
& & $\begin{array}{c}\text { Unstandardized } \\
\text { Residual }\end{array}$ \\
\hline $\mathrm{N}$ & & 50 \\
\hline Normal Parameters & & .0000000 \\
& Mean & 1.0222245 \\
\cline { 2 - 3 } Most Extreme Differences & Std. Deviation & .137 \\
\cline { 2 - 3 } & Absolute & .088 \\
\cline { 2 - 3 } & Positive & -.137 \\
\cline { 2 - 3 } & Negative & .137 \\
\hline Test Statistic & & $.288^{\text {c,d }}$ \\
\hline Asymp. Sig. (2-tailed) & & \\
\hline a. Test distribution is Normal. & \\
b. Calculated from data. & \\
c. Lilliefors Significance Correction. & \\
d. This is a lower bound of the true significance. & \\
Sumber : Hasil Pengolahan Data, 2020 &
\end{tabular}


Hasil uji normalitas Kolmogorov Smirnov pada tabel 2 menunjukkan bahwa nilai signifikan 0,288 > 0,05 dengan demikian hasil uji normalitas Kolmogorov Smirnov dapat diambil kesimpulan data berdistribusi normal.

Uji Multikolinearitas. Uji multikolinearitas digunakan untuk mengetahui ada atau tidaknya penyimpangan asumsi klasik dengan cara melihat hubungan linear antar variabel independen dalam model regres. Hasil pengujian multikolinearitas dalam penelitian ini adalah sebagai berikut :

Tabel 3. Pengujian Multikolinearitas

\begin{tabular}{|l|c|c|}
\hline \multicolumn{1}{|c|}{ Model } & Tolerance & VIF \\
\hline ln_Current Ratio & .313 & 3.197 \\
\hline ln_DER & .315 & 3.177 \\
\hline ln_Firm_Size & .981 & 1.019 \\
\hline
\end{tabular}

a.Dependent Variable:In_NPM

Sumber : Hasil Pengolahan Data, 2020

Berdasarkan tabel 3 menunjukkan nilai tolerance untuk variabel current ratio, debt to equity ratio dan firm size berada di atas 0,10 sedangkan nilai VIF variabel current ratio, debt to equity ratio dan firm size berada di bawah 10. Dengan demikian uji multikolinearitas tidak terjadi regresi antar variabel independen.

Uji Heteroskedastisitas. Uji Heterokedastisitas bertujuan untuk menguji apakah model regresi terjadi ketidaksamaan varian dari residual satu pengamatan ke pengamatan yang lain. Hasil pengujian heteroskedastisitas dengan menggunakan analisis grafik dapat dilihat dari grafik scatter plot sebagai berikut:

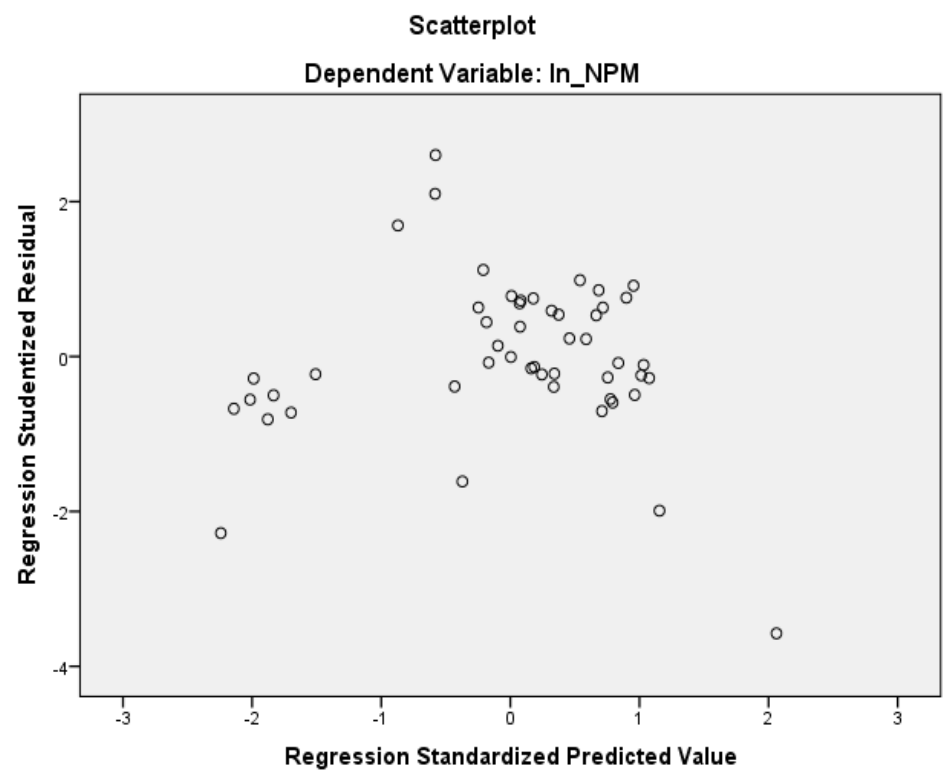

Gambar 3. Pengujian Heteroskedastisitas

Sumber : Hasil Pengolahan Data, 2020 
Dari grafik scatterplot terlihat bahwa titik-titik menyebar secara acak serta tersebar baik di atas maupun di bawah angka nol pada sumbu Y. Hal ini dapat disimpulkan bahwa tidak terjadinya heteroskedastisitas pada model penelitian ini sehingga model penelitian ini layak dipakai.

Uji Autokorelasi. Uji Autokorelasi adalah uji untuk melihat pengaruh antara variabel bebas terhadap variabel terikat, jadi tidak boleh ada korelasi antara observasi dengan data observasi sebelumnya. Hasil pengujian autokorelasi adalah sebagai berikut :

Tabel 4. Pengujian Autokorelasi

\begin{tabular}{|c|c|c|c|c|c|}
\hline \multicolumn{5}{|c|}{ Model Summary } \\
\hline $\begin{array}{c}\text { Mod } \\
\text { el }\end{array}$ & $\mathrm{R}$ & $\begin{array}{c}\mathrm{R} \\
\text { Square }\end{array}$ & $\begin{array}{c}\text { Adjusted R } \\
\text { Square }\end{array}$ & $\begin{array}{c}\text { Std. Error } \\
\text { of the } \\
\text { Estimate }\end{array}$ & $\begin{array}{c}\text { Durbin- } \\
\text { Watson }\end{array}$ \\
\hline 1 & $.478^{\mathrm{a}}$ & .229 & .178 & 1.05503 & 2.330 \\
\hline \multicolumn{2}{|l|}{ a. Predictors: (Constant), In_Firm_Size, In_DER, In_Current_Ratio } \\
\hline \multicolumn{3}{|l}{ b. Dependent Variable: In_NPM } \\
\hline
\end{tabular}

Sumber : Hasil Pengolahan Data, 2020

Berdasarkan tabel 4 menunjukkan hasil pengolahan data diperoleh nilai statistik Durbin-Watson(DW) sebesar 2.330. Apabila dilihat dari tabel uji Durbin-Watson pada signifikan 0,05 untuk jumlah variabel independen sebanyak 3 dan jumlah sampel sebanyak 85 diperoleh batas bawah nilai tabel $(\mathrm{dL})=1.550$ dan batas atasnya $(\mathrm{dU})=1.747$. Karena nilai DW $=2.330$ yang diperoleh lebih besar dari du dan lebih kecil dari nilai $(4-d u=4-1.747=$ 2.253 ) yaitu $1.550<2.330<2.253$ maka dapat disimpulkan hasil uji autokorelasi tidak terjadi autokorelasi positif dan negatif.

Pengujian Hipotesis. Pengujian hipotesis adalah langkah metode untuk melakukan pembuktian empiris atau mengkonfirmasi serta menolak sebuah opini ataupun asumsi dengan menggunakan data sampel. Persamaan regresi linear yang terbentuk dapat terlihat pada tabel 5 berikut :

Tabel 5. Persamaan Regresi Linear

\begin{tabular}{|c|c|c|c|c|c|c|}
\hline \multicolumn{7}{|c|}{ Coefficients $^{\mathrm{a}}$} \\
\hline & \multirow{2}{*}{ Model } & \multicolumn{2}{|c|}{$\begin{array}{l}\text { Unstandardized } \\
\text { Coefficients }\end{array}$} & \multirow{2}{*}{$\begin{array}{c}\text { Standardized } \\
\text { Coefficients } \\
\text { Beta }\end{array}$} & \multirow{2}{*}{$\mathrm{t}$} & \multirow{2}{*}{ Sig. } \\
\hline & & B & $\begin{array}{l}\text { Std. } \\
\text { Error }\end{array}$ & & & \\
\hline \multirow[t]{2}{*}{1} & (Constant) & -5.567 & 5.421 & & $\begin{array}{r}- \\
1.027\end{array}$ & .310 \\
\hline & ln_Current_Ratio & -1.304 & .635 & -.475 & 2.052 & .046 \\
\hline
\end{tabular}




\begin{tabular}{|l|l|r|r|r|r|r|}
\hline & ln_DER & -1.070 & .316 & -.781 & - & .001 \\
\cline { 2 - 6 } & & & & & 3.384 & \\
\hline
\end{tabular}

a. Dependent Variable: ln_NPM

Sumber : Hasil Pengolahan Data, 2020

$$
\text { Ln_NPM }=-5.567-1.304 \text { ln_Current_Ratio }-1.070 \text { ln_DER }+.825 \text { ln_Firm_Size }
$$

Dari persamaan regresi linear berganda, konstanta sebesar -5.567 menyatakan bahwa jika variabel independen dianggap konstan, maka nilai current ratio sebesar -5.567 menyatakan bahwa jika current ratio, debt to equity ratio, firm size bernilai nol maka nilai net profit margin tetap sebesar -5.567 kali. Variabel current ratio mempunyai koefisien regresi sebesar - 1.304 menyatakan bahwa pengaruh variabel current ratio terhadap net profit margin negatif. Apabila current ratio meningkat satu maka net profit margin akan turun sebesar - 1.304 kali. Variabel debt to equity ratio mempunyai koefisien regresi sebesar 1.070 menyatakan bahwa pengaruh variabel debt to equity ratio terhadap net profit margin negatif. Apabila debt to equity ratio meningkat satu maka net profit margin akan turun sebesar - 1.070 kali. Variabel firm size mempunyai koefisien regresi sebesar 0.540 menyatakan bahwa pengaruh variabel firm size terhadap net profit margin positif. Apabila firm size meningkat satu maka net profit margin akan naik sebesar 0.540 kali.

Uji Parsial. Uji parsial digunakan untuk dapat mengetahui apakah variabel independen secara parsial berpengaruh atau tidak terhadap variabel dependen. Berdasarkan hasil uji statistik t tampak secara parsial pengaruh kedua variabel terhadap variabel dependennya seperti ditunjukkan pada tabel 6 sebagai berikut :

Tabel 6. Uji Parsial (Uji t)

\begin{tabular}{|c|c|c|c|c|c|c|}
\hline \multicolumn{7}{|c|}{ Coefficients $^{a}$} \\
\hline & \multirow{2}{*}{ Model } & \multicolumn{2}{|c|}{$\begin{array}{c}\text { Unstandardized } \\
\text { Coefficients }\end{array}$} & \multirow{2}{*}{$\begin{array}{c}\begin{array}{c}\text { Standardized } \\
\text { Coefficients }\end{array} \\
\text { Beta }\end{array}$} & \multirow{2}{*}{$\mathrm{t}$} & \multirow{2}{*}{ Sig. } \\
\hline & & B & $\begin{array}{l}\text { Std. } \\
\text { Error }\end{array}$ & & & \\
\hline \multirow[t]{4}{*}{1} & (Constant) & -5.567 & 5.421 & & $\begin{array}{r}- \\
1.027\end{array}$ & .310 \\
\hline & ln_Current_Ratio & -1.304 & .635 & -.475 & $\begin{array}{r}- \\
2.052\end{array}$ & .046 \\
\hline & ln_DER & -1.070 & .316 & -.781 & 3.384 & .001 \\
\hline & ln_Firm_Size & .825 & 1.636 & .066 & .504 & .616 \\
\hline & & & & & & \\
\hline
\end{tabular}

Sumber : Hasil Pengolahan Data, 2020 
Hasil uji secara parsial (uji-t) variabel current ratio menunjukkan nilai $\mathrm{t}$ hitung $<\mathrm{t}$ tabel $(-$ $2.052<1.988)$ dan nilai signifikansi di bawah $0,05(0.046<0.05)$ yang berarti terdapat pengaruh signifikan antara variabel current ratio terhadap net profit margin. Hasil penelitian ini mendukung penelitian Angriani dan Hasanah (2017) yang menyatakan bahwa semakin optimal posisi likuiditas perusahaan akan semakin mendorong meningkatnya kemampuan perusahaan dalam menghasilkan laba yang diukur dengan net profit margin. Hasil penelitian ini tidak sejalan dengan Ritonga (2018), dengan current ratio (rasio lancar) rendah yang dimiliki perusahaan akan menunjukkan rasio likuiditas yang tinggi, sedangkan rasio lancar yang tinggi akan menunjukkan adanya kelebihan aktiva lancar, yang akan mempunyai pengaruh yang tidak baik terhadap profitabilitas perusahaan.

Hasil uji secara parsial (uji-t) variabel debt to equity ratio menunjukkan nilai $\mathrm{t}$ hitung $<\mathrm{t}$ tabel $(-3.384<1.988)$ dan sig.t sebesar 0.001 , sehingga secara parsial debt to equity ratio berpengaruh signifikan terhadap net profit margin pada perusahaan perdagangan besar produksi. Hasil penelitian ini mendukung penelitian Warsani dan Pramirza (2015), yang menunjukkan bahwa adanya hubungan DER dengan NPM bertolak belakang atau berbanding terbalik. NPM akan mengalami peningkatan apabila DER mengalami penurunan, begitu juga sebaliknya apabila DER mengalami peningkatan maka NPM akan mengalami penurunan serta tidak mendukung penelitian Koto (2017), debt to equity ratio tidak memiliki hubungan yang signifikan terhadap Net Profit Margin, ini artinya menurunnya debt to equity ratio tidak mempengaruhi penurunan atau peningkatan Net Profit Margin. Hal ini dikarenakan besarnya nilai rata-rata yang ditunjukkan memberikan arti bahwa peningkatan debt to equity ratio akan berdampak terhadap munculnya beban bunga yang harus ditanggung oleh perusahaan sehingga akan berpengaruh terhadap perusahaan untuk menghasilkan laba bersih yang maksimal sebab beban biaya yang ditanggung semakin tinggi.

Hasil uji secara parsial (uji-t) variabel firm size menunjukkan nilai $\mathrm{t}$ hitung $<\mathrm{t}$ tabel $(0.504<1.988)$ dan sig.t sebesar $0.616>0.05$, sehingga secara parsial firm size tidak berpengaruh signifikan terhadap net profit margin pada perusahaan perdagangan besar produksi. Hasil penelitian ini tidak mendukung penelitian Hastuti (2010) yang menyatakan bahwa perusahaan besar mempunyai pengendalian dan tingkat daya saing yang tinggi dibandingkan dengan perusahaan kecil, sehingga bisa digunakandengan perlindungan terhadap risiko ekonomis serta mendukung peneliian yang dilakukan oleh Suratminingsih (2018) menunjukkan bahwa ukuran perusahaan (Size) tidak berpengaruh signifikan terhadap profitabilitas (NPM).Sebagai faktor internal, pada umumnya ukuran perusahaan mempengaruhi segala aspek keuangan perusahaan termasuk pencapaian laba yang menjadi tujuannya, karena masyarakat yang menjadi end user atas produk yang dihasilkan perusahaan food and beverages terutama karakter pada masyarakat perkotaan yang memandang bahwa semakin besar ukuran perusahaan (Size), maka akan semakin tinggi pula kualitas atas produk yang dihasilkan dan layanan konsumen yang lebih komprehensif atas produk tersebut sehingga masyarakat cenderung lebih banyak memilih untuk menggunakan produk yang dihasilkan oleh perusahaan besar daripada produksi oleh perusahaan kecil, sehingga berdampak pada tingkat profitabilitas perusahaan.

Uji Simultan. Uji Simultan atau Uji F adalah uji yang digunakan untuk mengetahui apakah variabel independen secara simultan berpengaruh signifikan terhadap variabel dependen. Hasil Pengujian statistik simultan ditunjukkan pada tabel 7 berikut : 
Tabel 7. Uji Simultan (Uji F)

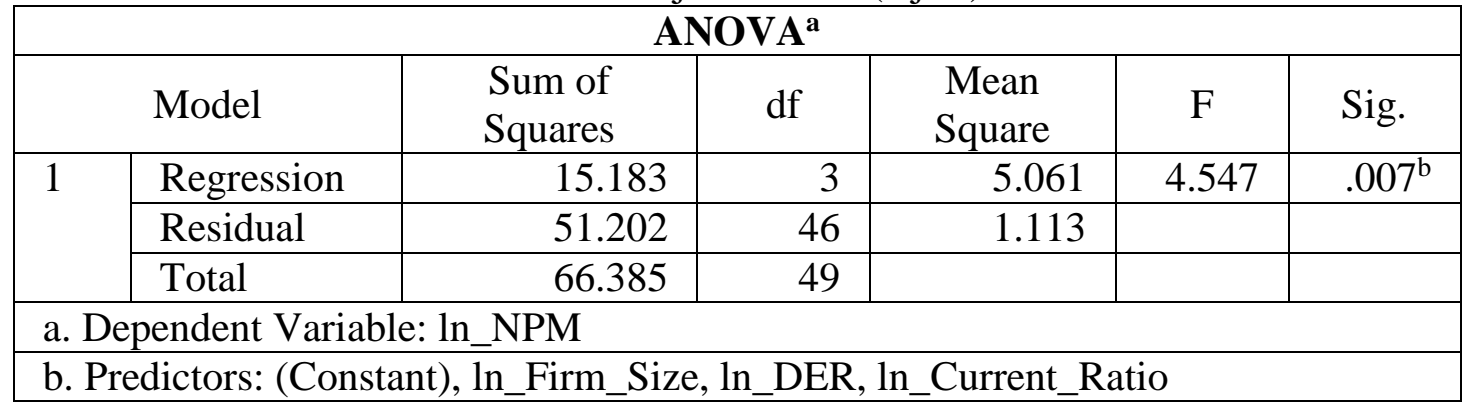

Sumber : Hasil Pengolahan Data, 2020

Hasil $\mathrm{F}$ hitung pada tabel 7 menunjukkan uji signifikansi simultan/bersama-sama (uji statistik F) menghasilkan nilai $F$ hitung sebesar 4.547. Pada derajat bebas $1\left(\mathrm{df}_{1}\right)=\mathrm{k}-1=4-1=$ 3 , dan derajat bebas $2\left(\mathrm{df}_{2}\right)=\mathrm{n}-\mathrm{k}=85-4=81$, dimana $\mathrm{n}=$ jumlah sampel, $\mathrm{k}=$ jumlah variabel, nilai $\mathrm{F}$ tabel pada taraf kepercayaan signifikansi 0,05 adalah 2.72 dengan demikian $\mathrm{F}$ hitung $=$ $4.547>\mathrm{F}$ tabel $=2.72$ dengan tingkat signifikansi 0,007 . karena probabilitasnya signifikansi jauh lebih besar dari sig 0,007 < 0,05, Maka Ha ditolak artinya secara bersama-sama Current Ratio, Debt to Equity Ratio dan firm size berpengaruh terhadap Net Profit Margin pada perusahaan perdagangan besar produksi besar yang terdaftar di Bursa Efek Indonesia tahun 2014-2018.

Uji $\mathbf{R}^{2}$. Uji $\mathrm{R}^{2}$ atau koefisien determinasi digunakan untuk mengetahui seberapa besar hubungan dari beberapa variabel dalam pengertian yang lebih jelas. Hasil perhitungan dapat dilihat pada tabel 8 berikut :

Tabel 8. Uji Koefisien Determinasi

\begin{tabular}{|c|c|c|c|c|c|}
\hline \multicolumn{6}{|c|}{ Model Summary $^{\mathbf{b}}$} \\
\hline Model & R & R Square & $\begin{array}{c}\text { Adjusted R } \\
\text { Square }\end{array}$ & $\begin{array}{c}\text { Std. Error of } \\
\text { the Estimate }\end{array}$ & $\begin{array}{c}\text { Durbin- } \\
\text { Watson }\end{array}$ \\
\hline 1 & $.478^{\mathrm{a}}$ & .229 & .178 & 1.05503 & 2.330 \\
\hline
\end{tabular}

Sumber : Hasil Pengolahan Data, 2020

Pada tabel 8 menunjukkan bahwa nilai koefisien determinasi disesuaiakan ( $R$ square) sebesar 22,9\%. Hal ini memiliki arti bahwa 22,9\% pengaruh net profit margin dapat dijelaskan oleh variasi dari ketiga variabel independen yaitu current ratio, debt to equity ratio dan firm size. Sedangkan sisanya sebesar $77,1 \%$ dijelaskan oleh variabel lain yang tidak diteliti pada penelitian ini.

\section{Simpulan dan Saran}

Simpulan. Dari hasil uraian sebelumnya dapat disimpulkan bahwa secara simultan pada hasil pengujian yang dilakukan secara simultan Current Ratio, Debt to Equity Ratio dan firm size berpengaruh terhadap Net Profit Margin pada perusahaan perdagangan besar produksi besar yang terdaftar di Bursa Efek Indonesia tahun 2014-2018. Dari hasil pengujian yang dilakukan secara parsial terjadinya pengaruh antara current ratio terhadap net profit margin, debt to 
equity ratio berpengaruh signifikan terhadap net profit margin, firm size tidak berpengaruh terhadap net profit margin pada perusahaan perdagangan besar produksi besar yang terdaftar di Bursa Efek Indonesia tahun 2014-2018 dan Sementara nilai koefisien determinasi disesuaiakan ( $R$ square) sebesar 22,9\%. Hal ini memiliki arti bahwa 22,9\% pengaruh net profit margin dapat dijelaskan oleh variasi dari ketiga variabel independen yaitu current ratio, debt to equity ratio dan firm size. Sedangkan sisanya sebesar $77,1 \%$ dijelaskan oleh variabel lain yang tidak diteliti pada penelitian ini.

\section{Saran}

1. Bagi perusahaan, perlu memperhatikan current ratio, debt to equity ratio dan firm size dan yang secara bersama-sama atau simultan dapat mempengaruhi profitabilitas perusahaan perdagangan besar produksi besar yang terdaftar di Bursa Efek Indonesia tahun 2014-2018. Perusahaan juga hendaknya lebih peduli dalam hal meningkatkan profitabilitas yang mempunyai pengaruh positif yang signifikan bagi perusahaan dalam pengambilan keputusan investasi.

2. Bagi investor, pengambilan keputusan yang baik dan tepat dalam hal berinvestasi untuk suatu perusahaan perlu analisis yang baik dalam hal analisis fundamental. Para investor juga hendaknya dapat mendorong perusahaan untuk melakukan profitabilitas untuk mendapatkan gambaran yang jelas mengenai kondisi perusahaan.

\section{DAFTAR PUSTAKA}

Anggriani, Devi dan Nurul Hasanah. (2017). Pengaruh Current Ratio, Debt to Equity Ratio Terhadap Net Profit Margin. Journal of Management Studies, 4(3).

Bambang dan Mulyo.(2015). Analisa Laporan Keuangan. Ed.5, Jakarta :Lentera Printing.

Fahmi, Irham.2015. Pengantar Manajemen Keuangan. (Cetakan Keempat). Bandung : CV. Alfabeta

Hastuti, Niken. (2010). Analisis Pengaruh Periode Perputaran Persediaan, Periode Perputaran Hutang Dagang Terhadap Profitabilitas Pada Perusahaan Manufaktur Tahun 2006 Sampai dengan 2008. Universitas Diponegoro, Semarang.

Hery. (2017). Teori Akuntansi: Pendekatan Konsep dan Analisis. Jakarta: Grasindo.

Hantono. (2017). Konsep Analisa Laporan Keuangan Dengan Pendekatan Rasio dan SPSS. Yogyakarta : Deepublis Publisher.

Kasmir. 2012. Analisis Laporan Keuangan. (Cetakan Kelima). Jakarta : Penerbit PT RajaGrafindo Persada.

Kadir, A., dan Phang, S. B. (2012). Analisis Faktor-Faktor Yang Mempengaruhi Net Profit Margin Perusahaan Manufaktur Yang Terdaftar Pada Bursa Efek Indonesia. Jurnal Manajemen dan Akuntansi, 13(1).

Koto, Murviana. (2017). Pengaruh Debt to Equity Ratio dan Current Ratio Terhadap Net Profit Margin Pada Perusahaan Farmasi Yang Terdaftar di Bursa Efek Indonesia. Jurnal Ilmiah Kohesi, 1(1), 134-147.

Munawir. (2014). Analisa Laporan Keuangan, Cetakan Ketiga Belas, Yogyakarta: Liberty Yogyakarta.

Rodoni, Ahmad dan Herni Ali. (2014). Manajemen Keuangan Modern. Jakarta: Mitra Wacana Media.

Riyanto, Bambang. (2015). Dasar - Dasar Pembelajaan Perusahaan. Yogyakarta: BPFE.

Ritonga, Dedi Boman dan Supriyanto Husnaini. (2018). Pengaruh Current Ratio, Debt to Equity Ratio, dan Net Profit Margin Terhadap Perubahan Laba Pada PT. Alumindo 
Light Metal Industry, Tbk di Bursa Efek Indonesia. https://doi.org/10.31227/osf.io/gcx45.

Sari, Purnama Warsani dan Agil Pramirza. (2015). Pengaruh Struktur Modal Terhadap Aktivitas Operasi Pada Perusahaan yang Terdaftar di Bursa Efek Indonesia. Jurnal Akuntansi dan Bisnis, 1(1).

Suratminingsih. (2018). Pengaruh Perputaran Piutang, Likuiditas, Leverage dan Ukuran Perusahaan Terhadap Profitabilitas. Akademika. 16(1).

Sartono, R. Agus. (2012). Manajemen Keuangan Teori dan Aplikasi. Yogyakarta: BPFE.

Sunyoto, Danang. (2013). Metodologi Penelitian Akuntansi. Bandung: Refika Aditama.

Samryn. (2013). Akuntansi Manajemen, Cetakan Kedua, Jakarta : Kencana Prenada Media. 